\title{
EDITORIAL
}

\section{0 sino que ressoa em tempos líquidos!}

Ressoar, soar, ou suar... Estas são palavras que se confundem em nosso consciente, claras na gramatica, e não na pratica. No nosso interior um turbilhão, um tsunami que se apresenta do nada e devasta tudo, o sino do consciente que soa e ressoa a voz da razão e da lucidez, mas que também exige, atitude, e responsabilidade, perspectivas que nem sempre alcançamos consigo mesmo e com a vida...

Assim neste turbilhão de ventos ficamos a suar para extravasar, jogar fora sentimentos não resolvidos, vontades não realizadas, coisas não ditas, caminhos adiados, que saem pelos poros, suam!

Por falta de condição, vontade, ou coragem, "um ruim que é bom" coisas do dito ser humano, que em seu pré-consciente se acha eterno, e quando toma as rédeas da vida, o tempo passou como o ressoar do sino, breve, forte, rápido e passageiro.

Como o sino ressoa o interior, há um grito que ressoa pelo som certo ou a resposta do caminho do som que ecoa e persiste em gritar, e murmurar o barulho da mudança, da esperança, ou mesmo da constância.

Um desorganizar e organizar da vida, que no momento se mostra como excessivamente suado, se dá na busca do vento brando que refresca e ressoa o sino interno. Traz o estado de amor como signo próprio, para levar aos amores, há amor! Palavra dita, falada, almejada e nem sempre praticada...

Diferente da paixão, num ressoar desgovernado como um vendaval que passa e leva quase tudo, o amor deixa um rastro que ressoa como um sino interno brando, refrescante e mensageiro das boas novas.

Nesta liquidez do ressoar do sino interno provocar-se pode liquefazer os sons internos e assim propor um encontro de si, e como um camaleão um recolher e uma adaptação aos novos sons que ecoam...

Há como encontrar o sino que ressoa!

\section{Boa Leitura!}

\section{Eliana Cristina Rosa}

Filósofa. Administradora Pública. Pedagoga. Especialista em Saúde Coletiva e Docência. Mestre em Gestão de Políticas Universitárias no Mercosul. Secretária Executiva da REFACS. 